\title{
Educação republicana sob a ótica de José Veríssimo ${ }^{1}$
}

\section{Republican Education under the optics of José Veríssimo}

\author{
Sônia Maria da Silva Araújo²
}

\begin{abstract}
RESUMO
Este artigo vincula-se aos estudos sobre o pensamento educacional no Brasil. Abordamos as interpretações de José Veríssimo sobre os problemas nacionais da educação brasileira no final do século XIX e início do século XX. Nossa intenção é apresentar e analisar estas interpretações, realizadas na Primeira República. José Veríssimo nasceu em Óbidos, no Pará, em 1857, e faleceu no Rio de Janeiro, em 1916, passando parte de sua vida intelectual no Pará e parte na capital da República, onde fundou e participou ativamente da Academia Brasileira de Letras (ABL) e da Revista Brasileira. O autor foi estudioso importante nas discussões sobre as consequências do colonialismo português e as tentativas frustradas de uma política republicana de educação no Brasil. Para José Veríssimo, a educação pública deveria estrategicamente superar as degenerescências raciais, especialmente localizadas nos sertões do Brasil, promovidas pela colonização. Os "Brasis" que sociologicamente constituíam o território nacional àquela época são pensados por Veríssimo como um entrave a ser superado pela República para a inserção do País na ordem moderna que, para ele, significava civilização. Mas esta civilização almejada se efetivaria, na sua perspectiva, na medida em que todos os brasileiros fossem incluídos em um projeto de unidade nacional.

Palavras-chave: José Veríssimo; raça; educação nacional.
\end{abstract}

\begin{abstract}
This article associates the studies about educational thought in Brazil. We approach the interpretations of José Veríssimo on the national problems of the Brazilian education in the end of the $19^{\text {th }}$ century and beginning of the
\end{abstract}

1 Este artigo resulta da realização do projeto de pesquisa Cultura e Educação em José Veríssimo: apontamentos para a compreensão da discriminação e do preconceito étnicos no Brasil, executado entre 2005-2007, com financiamento do Conselho Nacional de Desenvolvimento Científico e Tecnológico (CNPq).

2 Professora do Instituto de Ciências da Educação da Universidade Federal do Pará (UFPA). Coordena o Grupo de Pesquisa Constituição do Sujeito, Cultura e Educação (ECOS), Brasil. E-mail: somentesonia@hotmail.com. 
$20^{\text {th }}$ century. Our intention is to present and analyze these interpretations, carried through in the First Republic. José Veríssimo was born in Óbidos, Pará, in 1857, and died in Rio de Janeiro, in 1916. He spent part of his intellectual life in Pará and another part in the capital of the Republic, where he established and participated actively in the Brazilian Academy of Letters (ABL) and in the Brazilian Magazine (Revista Brasileira). The author was an important studious man in the discussions on the consequences of the Portuguese colonialism and the frustrated attempts to have some republican politics of education in Brazil. For José Veríssimo, the public education would have strategically overcome the racial degenerations promoted by the settling in Brazilian backlands. The "Brazis" that sociologically made the domestic territory to that time are thought by Veríssimo as an impediment to be overcome by the Republic for the insertion of the Country in the modern order that for him meant civilization. But this so called civilization would be effective under his perspective, as all the Brazilians were included in a project of national unit.

Keywords: José Veríssimo; race; national education.

\section{À guisa de reflexão inicial}

Discordância absoluta e radical entre as cidades e as malocas de telha do interior, que desequilibra tanto o ritmo de nosso desenvolvimento evolutivo e perturba deploravelmente a unidade nacional. Viam-se em terra estranha. Outros hábitos. Outros quadros. Outra gente. Outra língua mesmo, articulada em gíria original e pitoresca. Invadia-os o sentimento exato de seguirem para uma guerra externa. Sentiam-se fora do Brasil. A separação social completa delatava a distância geográfica; criava a sensação nostálgica de longo afastamento da pátria.

Os Sertões, Euclides da Cunha, 1995 [1902], p. 551.

As descrições de Euclides da Cunha e suas interpretações sociológicas sobre a Guerra de Canudos, especialmente sobre as distâncias e aproximações entre o brasileiro do litoral e o brasileiro do sertão, são, em grande medida, uma demonstração das denúncias que José Veríssimo coetaneamente vinha apresentando em seus contos sobre a vida da Amazônia e em seu texto intitulado $A s$ raças cruzadas do Pará: sua linguagem, suas crenças e seus costumes, presentes na obra Primeiras Páginas: viagens ao sertão, quadros paraenses e estudos, de 
1878. Já nesse momento, com apenas 21 anos de idade, Veríssimo revelava os antagonismos presentes na formação do povo brasileiro e que posteriormente servirão de elementos para a discussão que travará sobre as estratégias necessárias à superação dos limites que poderiam impedir a formação verdadeira de uma civilização brasileira.

Os "Brasis" que sociologicamente constituíam o território nacional àquela época são pensados por Veríssimo como um entrave a ser superado pela República para a inserção do País na ordem moderna que, para ele, significava civilização, isto é: alta cultura, fundamentada nas Artes, Literatura e Ciência. Mas esta civilização almejada se efetivaria, na sua perspectiva, à medida que todos os brasileiros fossem incluídos em um projeto de unidade nacional.

\section{$O$ autor e as bases de suas inquietações}

Segundo Peregrino Junior (1957) - autor que viveu de 1898 a 1983 e escreveu um texto biográfico sobre José Veríssimo, intitulado José Veríssimo: homem de carne e osso, publicado pela Revista da Academia Brasileira de Letras -, José Veríssimo nasceu, em termos literários e filosóficos, em um tempo muito próspero e pertenceu a uma das gerações mais ricas e ilustres. De fato, Veríssimo nasceu em Óbidos, no Pará, em 1857, e faleceu no Rio de Janeiro, capital, em 1916. Passou parte de sua vida intelectual no Pará e parte na cidade do Rio. Foi um pensador reconhecido nas discussões sobre as consequências do colonialismo português no Brasil e as tentativas frustradas de uma política republicana de educação para o País.

José Veríssimo faz parte de uma geração de pensadores que vivia no Brasil o processo de transição do império para a República em meio a uma formação política, filosófica e sociológica importada da Europa e dos Estados Unidos da América em que prevaleciam interpretações liberais, positivas e evolucionistas do mundo e das sociedades humanas. É evidente que, ao serem transpostas para a compreensão da realidade brasileira em particular, estas interpretações acabaram por apresentar vários desdobramentos.

Referência da crítica dos primeiros anos de república, José Veríssimo se colocou, no contexto dessa geração, como uma voz do norte do Brasil que tentava denunciar as desigualdades produzidas pelo processo de colonização ao revelar, principalmente por meio de seus contos, as condições miseráveis nas quais se encontravam os mestiços da Amazônia. Mas, destacadamente, apontava soluções. 
Para ele, a transformação dessas condições só poderia ocorrer por meio de um projeto nacional de educação capaz de nos fazer iguais de norte a sul do País.

Exímio conhecedor da realidade sociocultural do norte do Brasil, José Veríssimo foi um etnógrafo da vida dos povos miscigenados desta região, como defende Bezerra Neto (1999), e um debatedor incansável de seus modos de viver e agir. Na condição de jornalista e homem público, que ocupou cargos importantes no Pará, como o de Diretor da Instrução Pública, entre 1880 e 1891, José Veríssimo teve a oportunidade de pensar criticamente as condições objetivas de existência dos mestiços da Amazônia e, não raro, responsabilizou o processo de colonização portuguesa, e o desempenho pífio dos primeiros anos da República no campo da educação, pela pobreza econômica e falta de oportunidade escolar para estes brasileiros. ${ }^{3}$

$\mathrm{Na}$ verdade, Veríssimo acreditou, a princípio, que o regime republicano resolveria os problemas criados pela colonização e, nessa direção, foi um crítico contundente das políticas por ele promovidas. A República brasileira, na sua concepção, deveria superar os desníveis regionais presentes no território nacional, principalmente no que se refere ao acesso à educação escolar. Defensor intransigente da formação cultural de um povo para o seu bom desenvolvimento econômico e político, Veríssimo acreditava que por meio do acesso à escola os povos mestiços empobrecidos do norte seriam capazes de superar as degradações de sua raça. Explicando melhor: Veríssimo aliava pobreza às condições econômicas mal exploradas na região da Amazônia; articulava moral degradada à questão da raça; e apontava a educação escolar como um processo necessário à superação de ambas, isto é, da pobreza e da moral degradada. A educação era um objeto de análise candente em Veríssimo, para quem a glória, a honra e a própria felicidade material do povo do Pará, e da Amazônia de um modo geral, não poderiam reduzir-se à produção da borracha. A preocupação com a instrução do povo, com a educação, era evidente no seu discurso e ele insistia ser necessário construir no Pará uma intelectualidade.

Sob esse espírito investigativo, Veríssimo analisa as propostas de educação nacional nos primeiros anos republicanos. Criado o Ministério da Instrução Pública, Correios e Telégrafos, logo após a proclamação da República, Benjamin Constant procedeu à reforma do sistema geral de ensino público. José Veríssimo discutiu, no Jornal do Brasil, em 1892, as reformas introduzidas - que depois

3 Os limites da República brasileira (enquanto regime político socialmente instituído) são abordados, dentre outras obras, em: Os sertões, de Euclides da Cunha; A formação das almas: o imaginário da república no Brasil e Os bestializados: o Rio de Janeiro e a República que não foi, de José Murilo de Carvalho; O sertão prometido: o massacre de Canudos no nordeste brasileiro, de Roberto M. Levine; A primeira república e O tenentismo, de Edgar Carone. 
ele acresceu como Introdução da $2^{\mathrm{a}}$ edição (1906) de seu livro $A$ Educação Nacional -, não se detendo apenas nas enormes insuficiências da educação escolar como ele a conheceu e sentiu no seu Estado, mas repassou, com límpida visão de sociólogo, muito da realidade doméstica e social do Brasil daquele tempo, com os vícios que a corrompiam, e que o secular regime da escravidão havia arraigado profundamente.

\section{Educação nacional contra a desordem do progresso: uma questão de raça e de cultura}

Na condição de educador, mais: de um político da educação, José Veríssimo apresentava discussões sobre os destinos da educação no Brasil e sua importância na vida da República. Prisco (1937) escreve, em seu livro José Veríssimo: sua vida e suas obras, um capítulo intitulado José Veríssimo - O Pedagogo, defendendo que em Veríssimo a educação foi o "maior apostolado de sua vida e por ella, desde os tempos de moço até a idade provecta, dispendeu grande parte de sua actividade" (PRISCO, 1937, p. 51-2). ${ }^{4}$

É sob a regência desse espírito que José Veríssimo expõe, em $A$ Educação Nacional, sua preocupação, e, no ardor de sua consciência idealista, a decepção com os rumos que a República tomou ao ignorar as graves questões da educação no Brasil:

Este livro foi escrito logo após a proclamação da República. Não me receio de dizer que o foi com a máxima boa fé e sinceridade. Meditei-o e escrevi-o na doce ilusão e fagueira esperança de que

4 Informa Prisco que José Veríssimo publicou na Revista Educação e Pediatria alguns textos que iriam se constituir na obra História da Instrucção Pública no Brasil, mas ficou inconclusa. Publicou na revista de ${ }^{\circ}$ 1: Antecedentes Históricos de Ensino Público no Brasil e Os jesuitas e as reformas de Pombal; no $\mathrm{n}^{\circ}$ 2, a lição inaugural do curso feito no Pedagogium. Nos números 6 e 7 (nov. e dez. de 1913) publica o estudo A Companhia de Jesus e o Ensino. Nos números correspondentes a abril e dezembro de 1914, Outros fatores da instrução no Brasil-Ordens Religiosas; seu ensino - Seminários Episcopaes. Na Revista Educação Nacional publicou os seguintes artigos: $O$ mal do nosso ensino público; O ensino da História na Escola Normal; O ensino municipal do Rio de Janeiro. Na Revista Brasileira (fascículo 11, de 1895) publicou a lição inaugural de Pedagogia, dada no Pedagogium. Na Educação e Ensino, em que só saíram 5 números, há trabalhos de Veríssimo: A Educação em Geral, A Pedagogia, A Educação physica. Pela Imprensa Nacional há o trabalho Condições a que devem satisfazer os livros destinados ao ensino primário (PRISCO, 1937). 
o novo regime, que só o propósito de ser de regeneração para a nossa pátria legitimaria, havia realmente de ser de emenda e correção dos vícios e defeitos de que os seus propagandistas, entre os quais me poderia contar, levaram mais de meio século a exprobrar à monarquia.

Ao seu ingênuo autor, desde a juventude dedicado, com ardor e estudo, às questões de educação, parecia que tanto a filosofia especulativa como a experiência da humanidade certificavam-se que o meio mais apto, mais profícuo, mais direto e mais prático de obter emenda e correção, era a educação. (VERÍSSIMO, 1906, p. 5-6).

Com base na percepção de que a República representava descentralização do poder na mão de um soberano (traço fundador da monarquia) $)^{5}$ e de que, portanto, a educação como bem comum seria partilhada por todos, Veríssimo acreditava que o Brasil republicano alargaria as oportunidades ao estender educação a todos. Ao entender a educação como bem público, ele vislumbrou - ignorando as relações políticas clientelísticas estabelecidas pelo colonialismo - que a República, já nos seus primeiros anos, garantiria educação indiscriminadamente. Certo de que o estado de direito estaria assegurado pela res publica, Veríssimo confiou na superação das desigualdades sociais e da exclusão a que estavam submetidos os mestiços localizados nos sertões do Brasil. ${ }^{6}$

Inspirado no modelo republicano francês - fundado categoricamente na ordem pública, que tem como desdobramento democrático a ideia de que o progresso da razão é possível pela instrução ao alcance de todos -, Veríssimo defendia que o Brasil deixaria de ser um país dependente e colonizado a partir do momento em que se promovesse, no interior da cultura brasileira, o espírito de cidadania, isto é: o aprendizado em comum das virtudes cívicas, o respeito à vida coletiva e o gosto pela cultura civilizada. Isto porque para ele a colonização não tinha conseguido suplantar a barbárie, nem eliminar os vestígios degenerescentes das raças que constituíram, limitadamente, o mestiço brasileiro.

Assim, como outros pensadores de seu tempo, identifica os espaços do território nacional onde não houve desenvolvimento econômico e social como o Brasil do atraso. É com base nessa constatação, pautada no conhecimento

5 Cf. Norberto Bobbio (1986); Celso Laffer (1989, p. 214-224).

6 No entanto, a carta da Primeira República do Brasil, imposta por uma elite oligárquica, é um verdadeiro documento de exclusão ao privar do direito de voto os analfabetos (a grande maioria do povo brasileiro àquela época, aproximadamente $85 \%$ ) e desobrigar o Estado de promover instrução primária a todos. 
empírico que tinha da Amazônia, especialmente dos lugares mais desprovidos de bens materiais da vida "civilizada", que Veríssimo acusará o governo republicano de inoperância e falta de seriedade. Viajante do interior da Amazônia e arguto observador da vida social dos povos da floresta, Veríssimo escreveu os primeiros ensaios descritivos sobre grupos humanos situados neste espaço e fez interpretações críticas da história de ocupação promovida pelos portugueses ao inter-relacionar condições físicas do meio, moral do miscigenado do norte e o pouco investimento econômico na região. Nas descrições que ele faz do homem amazônico e sua terra não são raras as vezes em que relaciona as condições físicas da floresta com os modos de agir e pensar de seu povo. Assim, por vezes, o social, em sua obra, parece ser uma extensão do físico e vice-versa. Todavia, os elementos históricos e políticos irrompem suas descrições deixando emergir um crítico historiador avançado para o seu tempo.

Essa realidade demográfica e social tão bem conhecida por José Veríssimo a Amazônia - será expressa por meio de seus contos regionais, como O Lundun, O boto, $O$ crime do tapuio, $O$ voluntário da pátria, Sorte de Vicentina, Indo para a seringa, Voltando da seringa e $A$ Mameluca. A crítica à moral dos mestiços do norte aparecerá nessa literatura marcada por interpretações pautadas no positivismo de Comte, no evolucionismo de Spencer e no determinismo de Taine sobre o meio. É por isso que Veríssimo insistirá na necessidade da República alterar as condições naturais da região ao investir em seu povoamento e, por extensão, na ampliação do mestiçamento, já que a população nativa era, em grande parte, desprovida de valores morais capazes de garantir a modernidade, pois, para ele, o mestiço formado pelo índio, negro e português não tinha resultado em uma raça capaz de construir um País forte, soberano e livre. Após longa descrição dos cruzamentos raciais no Brasil (branco com índio, branco com preto, preto com índio), ele afirma que "em geral, cada novo cruzamento approxima o mameluco, o filho do branco e do índio (curibóca, ou mameluco propriamente dito) da raça branca" (VERÍSSIMO, 1887, p. 299). Essa ideia será posteriormente corrigida por Veríssimo que fará ressalvas, anos depois, sobre as qualidades de caráter das raças indígena e negra.

As condições materiais tão precárias do norte eram, na concepção de Veríssimo, um empecilho ao seu crescimento social, econômico e político. A distância da região do poder central precisava ser superada, segundo ele, por processos avançados de comunicação e por investimentos infraestruturais. Essa falta de condições adequadas acabava por inviabilizar a qualidade da instrução pública, já que as ações do governo não chegavam até lá e a própria população não tinha a formação necessária para questionar as decisões dos dirigentes locais em virtude de não possuir esclarecimento do que é bom ou ruim para si mesma. Este isolamento da região é, inclusive, ratificado por Euclides da Cunha, em $\grave{A}$ 
margem da história. Ao se referir ao abandono a que são submetidos os sertanejos na Amazônia, por ocasião da extração da borracha, este autor sublinha: "o sertanejo emigrante realiza, ali, uma anomalia sobre a qual nunca é demasiado insistir: é o homem que trabalha para escravizar-se". Mais adiante completa que o seringueiro ali é "obrigatoriamente, profissionalmente, um solitário" (CUNHA, 1999 [1909], p. 36).

Veríssimo refere-se ao povo brasileiro, especialmente o situado no território Norte, como sendo humilde, hospitaleiro, indolente, sem instrução, analfabeto e ocioso. A partir dessa ótica, digamos, trágica, e levando em consideração as raízes históricas e culturais do País, ele trata a República brasileira como um projeto a ser realizado, pois não vinha dando demonstrações de que suplantaria os problemas promovidos pela colonização como: a degradação racial; o meio inóspito; as péssimas condições sociais, políticas e religiosas; o predomínio cultural da raça tupi. Ainda que se valendo de uma contundência injusta em seus julgamentos sobre a moral mestiça, é Veríssimo quem traz para o cenário nacional, no final do século XIX e início do século XX, a realidade dos confins da Amazônia, que contribuirá, avolumada pelas descrições feitas até então sobre o interior do sertão do nordeste com a constituição do mapeamento social dos diversos agrupamentos brasileiros e, por extensão, na reflexão crítica a respeito das políticas necessárias para a formação de um Estado verdadeiramente fundado nas condições sociais, culturais, políticas e econômicas de seu território. Veríssimo foi um pensador social incansável em defender que qualquer mudança no País só ocorreria mediante um profundo conhecimento de suas díspares realidades e, para isso, era preciso mergulhar no complexo caldeamento racial que fez aparecer os diversos homens brasileiros. A partir do conhecimento dessa base social seria possível prescrever as mudanças. Desse caldeamento, Veríssimo via o mestiço como uma raça inferiorizada pela história a que fora submetido.

Com base nessa história, nosso autor defende o passado de glória dos índios antes do contato com o branco português e diz que "[...] o selvagem do Brazil antes da sua perseguição tinha um grao maior de civilização do que hoje". (VERÍSSIMO, 1878, p. 147).

Sob essa lógica, ele critica a barbárie dos brancos, dos catequéticos que escravizaram, subjugaram e exploraram o índio. Para reforçar isto, Veríssimo recorre a documentos e relata as atrocidades cometidas pelos colonos que mandavam marcar, com ferro em brasa, no peito dos índios escravos, o nome de seu senhor.

Essa violência, destacada por Veríssimo, é conjugada à crítica ao processo de educação a que foram submetidos os indígenas, indicando que o problema da degradação do "selvagem" se deve, dentre outras causas, ao tipo de educação 
provida pelos jesuítas, além do atraso intelectual dos portugueses e a intolerância do clero.

Mais afeito a uma transformação pacífica da sociedade pela educação, Veríssimo absorveu as ideias positivas que vinham da Europa com muito mais força que as materialistas. A consciência crítica que tinha da realidade brasileira freava-se pelo conservadorismo da classe a que pertencia, isto é, uma classe média que se firmava pela urbanização das cidades e formação burocrática dos serviços públicos necessários à institucionalização do novo regime. Não é por acaso que José Veríssimo, ainda que crítico contundente do governo, mantinhase, sem sobressaltos, nos cargos públicos que ocupava.

A crítica promovida por Veríssimo era, assim, muito mais conservadora que radical; suas propostas muito mais renovadoras que revolucionárias, o que não lhe tira o mérito de ter denunciado, com conhecimento de causa, os problemas políticos dos primeiros anos de república; de ter-como nenhum outro pensador da geração da qual fez parte - descrito a dura realidade educacional do País, denunciado os equívocos das políticas de instrução pública propostas e apresentado alternativas viáveis e exequíveis de implementação para o sistema educacional à época.

Essas críticas e propostas serão posteriormente encampadas por movimentos em defesa da modernidade do País já nos primeiros anos da década de 1920, particularmente sua defesa por uma cultura verdadeiramente brasileira, pautada na realidade nacional, como a que vimos ser reunida por Mário de Andrade, que percorreu todo o território registrando manifestações populares e práticas culturais.

Os fundamentos teóricos da crítica literária de Veríssimo, especialmente os decorrentes do determinismo de Taine sobre o meio, e do qual já falamos, vão estar presentes nas suas análises sobre a realidade cultural brasileira de um modo geral e direcionar suas interpretações sobre o sistema educacional. Todavia, o "meio", nas análises de Veríssimo, apresenta desdobramentos mais consequentes porque ele acrescenta a este as contingências históricas e culturais na produção da vida nacional.

Na própria história de Veríssimo pode estar a explicação do avanço de suas interpretações sobre o determinismo do meio na formação do caráter do povo e da própria produção literária nacional. Militante engajado no movimento abolicionista no Pará e um observador atento do sertão e do litoral, conseguia perceber o quanto os processos diferenciados de ocupação do território ao longo da história colonial promoveram também culturas, ou melhor, níveis de cultura diferenciados. Portanto, o fator cultural (visto por ele como fundamentalmente histórico) estava a articular suas compreensões sobre a relação entre cultura e educação. 
Veríssimo ressalta o quanto o modo como o processo de miscigenação no período colonial constituiu grupos com modos de ser, de viver, de pensar e de sentir muito diferenciados. O clima, a vegetação, advindos das leituras que fez de Spencer, são apresentados como fatores importantes no modo como os colonizadores atuaram no norte do País, ${ }^{7}$ mas também como os interesses econômicos e políticos foram reconfigurando o caráter destes e produzindo uma nova raça. A crítica à ambição econômica, já no Brasil república, por ocasião da exploração da borracha na Amazônia, é evidente em suas narrativas e descrições, especialmente em Indo para a seringa e Voltando da seringa. As práticas culturais que vão se constituindo em tradição no interior do norte, e que são detalhadamente descritas por ele, revelam o olhar de um realista histórico. Trata-se de um crítico afeito aos matizes sociais que as histórias locais provocaram e que, não raro, promoveram estados de profunda miséria, ignorância e alienação.

Em meio a essa multiplicidade de fatores que constituem o sujeito, Veríssimo reforça sempre a importância da educação. Para ele as culturas degradadas pelo mestiçamento de raças inferiores precisavam ser "lapidadas" por um projeto público de educação, isto porque a mistura resultou, segundo ele, em um tipo de gente cujos modos de ser, viver, pensar e sentir não se coadunavam com a nova ordem econômica, social e cultural na qual o País estava sendo compelido a entrar - a modernidade. Nesse sentido, a lógica que rege as interpretações de Veríssimo, que tinha em seu horizonte a formação de um país civilizado, era a de que não era esta nova ordem que precisava mudar, mas os sujeitos que aqui foram conformados. Então, que se mudassem esses sujeitos; que os colocassem dentro da ordem dessa sociedade que, por ser civilizada, deveria assumir-se como nação.

Essa ideia de nação, e por extensão de nacionalismo moderno, tão fortemente presente em Veríssimo, tem suas raízes no romantismo de Rousseau para quem o amor à pátria é o meio mais seguro de se tornar cidadão, e a constituição do Estado moderno a via necessária para a garantia da felicidade e liberdade de todos. ${ }^{8}$ É por isso que Veríssimo insistirá tanto na ideia de que as raças miscigenadas são apátridas. Ele via nos grupos humanos miscigenados do Pará, por exemplo, a total ausência de sentimento pátrio ao tempo em que constatava, por parte do governo republicano, um absoluto descaso para com as condições de existência dessas populações. Como a constituição do Estado-nação era fato, portanto irremediável e por isso necessário, ele, estrategicamente, investirá em

7 Spencer (1820-1903), filósofo inglês, foi profundo admirador da obra de Charles Darwin e é considerado o "pai" do darwinismo social, pois procurou aplicar as leis da evolução a todos os níveis de atividade humana.

8 Rousseau (1712-1778), um expoente do romantismo francês, defende, em $O$ contrato social, 1762, os ideais democráticos republicanos, centrados na ideia de liberdade como participação ativa na política e na legislação. 
um discurso fortemente político ao colocar a educação escolar pública como a medida mais imediata e necessária do governo republicano.

Mas a estratégia de Veríssimo vai mais além quando, baseado em Herder - filósofo e historiador do romantismo alemão, para quem a história constitui o homem e que, portanto, não há uma natureza que nos torne humanos -, coloca em pauta a ideia de que a nação brasileira só se constituiria como tal na medida em que produzisse uma cultura também brasileira. Por isso, ele será um árduo defensor de uma literatura brasileira. ${ }^{9}$ Neste caso, a ideia de que "minha língua é minha pátria" terá lugar privilegiado na lógica discursiva de Veríssimo, o que lhe renderá o ódio incontrolável de Sylvio Romero, já que este via a crítica de Veríssimo à cópia de ideias estrangeiras (o estrangeirismo) nos escritos intelectuais do Brasil como um atentado a sua capacidade crítica, a de Tobias Barreto, enfim, a todos que tinham participado efetivamente da Escola do Recife. Para Sylvio Romero

o conhecimento profundo d'um povo, existente ou extincto, não reclama indispensavelmente a posse da língua d'esse povo. Os grandes espíritos, dotados de intuição quase divinatória, não precisam d'essa alma. Bastam-lhe outros documentos, outras fontes de informação e inspiração (1909, p. 49).

Para Veríssimo a literatura, ao se nacionalizar, isto é, ao ter por base a vida brasileira e não mais a da metrópole, retornaria à grande maioria da população se esta tivesse um projeto público de educação pautado em dados dessa literatura. É por isso que defenderá arduamente uma geografia pátria, uma história pátria etc. ${ }^{10}$ Do ponto de vista historiográfico, ele pensava que a formação de uma consciência critica, isto é, de sujeitos atuantes, responsáveis pelo destino do País, só ocorreria se sua própria história, suas tragédias, não fossem esquecidas por serem lembradas pelo ensino público de história. Mais: que era preciso construir uma história da literatura brasileira e foi por isso que investiu tanto, se empenhou mesmo em dar continuidade à escrituração dessa história. A importância do discurso literário é tão grande para Veríssimo na construção da nação

9 Para Hami Bhabha é a partir das tradições do pensamento político e da linguagem literária que a nação surge, no Ocidente, como uma poderosa ideia histórica. Daí a importância do discurso literário na construção da identidade nacional. Um povo que não tem literatura não é uma nação (BHABHA, 1997).

10 Sobre o ensino de História pensava Veríssimo que ele deveria ser ministrado entremeado de contos populares e lendas para que os fatos históricos despertassem o orgulho da nacionalidade, o amor da sua terra e da sua gente. 
que não se conformava em, apenas narrar a nação por meio da literatura; era preciso legitimar essa literatura e contar sua história.

Mas não era qualquer um que poderia criar, construir essa literatura e sua história, mas sim uma classe média engajada, atuante, formada de espíritos superiores, como o de Machado de Assis. Nesse aspecto, as vozes do racismo inglês (e também do Romantismo), para o qual uma clerezia de intelectuais literatos era capaz de transformar os estados de natureza dos mais ignorantes, isto é, que os heróis e os gênios de raça reformariam o social, passa a fazer parte do discurso de Veríssimo. Enfim, pela produção de uma literatura realista da vida brasileira, elaborada por sujeitos de genialidade inata, e divulgada pela instrução pública de ensino, tudo o mais se transformaria em direção à vida civilizada, à formação do espírito moderno no Brasil.

\section{À guisa de reflexões finais}

Na verdade, era Veríssimo um pensador da realidade brasileira que denunciava o atraso no qual estava mergulhado o País e que, na sua perspectiva, precisava ser superado para que ingressasse na vida moderna. A literatura e a educação pública eram o fluxo por onde a formação da cidadania ocorreria e o espírito democrático se formaria no conjunto de uma sociedade verdadeiramente brasileira. Neste sentido, foi Veríssimo um pensador militante, incansável mesmo ao expor as mazelas sociais produzidas pela colonização, ao denunciar as iniciativas tímidas da República e, o que é mais importante, indicar propostas; apresentar soluções.

Mas também foi um idealista porque pensava a mudança a partir de um projeto a ser feito e não a partir da realidade mesma, dos sujeitos ali estados. Enfim, pensava em uma mudança que viesse "de cima", elaborada "no gabinete" e que a todos incluísse, isto é, uma mudança sem luta, sem perdas, sem dor. De espírito pacífico, Veríssimo morreu sem ver essa possibilidade ser tentada e, na sua solidão angustiada, desencantado com a República que ajudou a construir.

Ao etnografar os povos miscigenados da Amazônia e fundamentar as tramas construídas em seus contos em dados reais de seu interior para, então, defender a urgência de um projeto público de educação capaz de incluí-los em um Estado civilizado (que via existir em alguns centros urbanos do País), Veríssimo acabou por resvalar em uma interpretação extremamente estereotipada destes e até certo ponto racista, e é ele próprio quem tenta, em republicações de seus próprios escritos, retificar esta postura. Na segunda publicação de As raças cruzadas do Pará: sua linguagem, suas crenças e seus costumes, ocorrida em 1887, portanto, 
nove anos depois da primeira publicação, e com o título alterado para As populações indíjenas e mestiças da Amazônia: sua linguagem, crença e seus costumes, Veríssimo reconhece ter sido "injusto" com as populações mestiças e tenta "corrigir" algumas interpretações fortemente preconceituosas para com índios e negros. Argumentando ter aprofundado estudos posteriormente, vai defender que a força natural dos povos primitivos é que possibilitaria a formação de um povo diferente na América, mais forte e vigoroso.

Esta "nova" postura corrige ideias muito presentes na primeira publicação do autor sobre os "selvagens" da Amazônia e que se encontravam profundamente fundamentadas na teoria da degenerescência das raças de Gobineau (1816-1882), para quem a miscigenação era inevitável e levaria a raça humana a graus sempre maiores de degenerescência, tanto física quanto intelectual já que nesse processo é a raça inferior que acaba preponderando. Agora, mais adepto ao evolucionismo, Veríssimo, já absorvendo a ideia liberal da "sobrevivência dos mais aptos", defenderá que a miscigenação melhoraria a "nossa raça", pois nos tornaria mais distantes das práticas degenerescentes de "nossos ancestrais primitivos" ao tempo em que nos faria mais fortes porque firmados naquilo que se revelou verdadeiramente resistente. No que pesem seus pedidos de desculpas, Veríssimo não deixa de trabalhar no terreno das teorias raciais.

Portanto, sintonizado com as ideologias promovidas na Europa - especialmente França, Inglaterra e Alemanha, de onde lia com ardor seus intelectuais -, Veríssimo incorporará, a princípio sem críticas, o pensamento racial que ali se produzira e que, posteriormente, deu origem à Segunda Grande Guerra. O racismo, enquanto ideologia, se pôs no pensamento de Veríssimo que, na condição de homem justo, reflexivo, crítico e sensível às condições dos mais oprimidos e degradados, logo fará as "correções" e construirá explicações rearranjadas de suas próprias interpretações. Na verdade esse racismo se impõe ao pensamento de Veríssimo até o momento em que ele se coloca como adepto dos "pregadores científicos" e do patriotismo.

Mas as interpretações constantes nos ditos escritos de Veríssimo são bastante ambíguas e revelam um pensador dividido: o do interior - que viveu e percebeu a realidade simples do interior da Amazônia, e que não raro era utilizada para depreciá-lo (Sylvio Romero (1909), por exemplo, se vale a exaustão da origem de Veríssimo para criticá-lo) - e o da capital - que assimilou as teorias debatidas no contexto da capital, o Rio de Janeiro. O Veríssimo do interior aprecia sua gente e a Amazônia, constata qualidades na vida simples do Pará. O Veríssimo da capital rejeita essa vida simples, vê nela problemas e reputa como necessária a sua mudança de modo que não se constituísse em um empecilho para o ingresso do País no mundo civilizado. Por vezes não raras essas ambiguidades saltam em comentários aparentemente banais. Em correspondência a Afrânio Peixoto, 
ao traçar comentários sobre a Esfinge, ele revela o que pensa sobre nossa gente, nossa sociedade de um modo geral quando diz: "Esfinje é a reprezentação exata, quazi sintética e simbólica, da nossa sociedade misturada, incoerente, heterojenea, simiesca, inconscientemente imoral, triste imajem de um momento mizeravel da nossa vida histórica" (ACADEMIA BRASILEIRA DE LETRAS, 1930a, p 97).

Em correspondência posterior ao próprio Afrânio Peixoto, por ocasião de seu retorno ao jornal o Imparcial, ele revela: "Este maldito dezejo de exteriorizar-nos em opiniões, idéas e conceitos, este gosto muito de literatos [...] é também, como tantas outras, da raça, do meio, da educação, uma deplorável cauza de fraqueza" (ACADEMIA BRASILEIRA DE LETRAS, 1930b, p.108, grifos nossos).

Contraditoriamente, em análise crítica à obra de Gregório de Mattos, Veríssimo destaca, em tom de crítica, a repulsa do autor para com negros e mulatos, chamados por ele [Gregório de Mattos] de cães. Assim, Veríssimo (1912, p. 38) destaca o poema Milagres de Brazil, que diz:

\author{
Um branco muito encolhido \\ Um mulato muito ousado, \\ Um branco todo coitado, \\ Um canaz todo atrevido. \\ O saber muito abatido \\ A ignorância e ignorante \\ Muito ufano e mui farfante \\ Sem pena ou contradição: \\ Milagres do Brasil são.
}

Na condição de abolicionista, Veríssimo não mediu esforços em anunciar a necessidade do País "virar a página", superar o escravismo e instituir de vez o trabalho assalariado. Ele foi, sem sombra de dúvida, uma voz importante no Pará, quando publicou escritos em defesa do fim da exploração dos negros, mas isto não significava que ele admitisse que o negro tivesse as mesmas condições potenciais dos brancos. Suas denúncias eram, evidentemente, contra a escravidão enquanto instituição.

Por fim, Veríssimo (1887) diz acreditar que a missão história da América talvez fosse a de produzir uma "unidade étnica à humanidade". Ao fazer este prenúncio ele, na verdade, está defendendo a miscigenação porque acreditava que ela, como já dissemos, promoveria um povo distante de seus ancestrais degenerados. Quando trata da falta de moral entre as populações miscigenadas, se 
reporta sempre aos fatores raciais e a uma certa libertinagem na vida do selvagem. Os elogios que faz aos portugueses, que tanto criticava, ao compará-los com os ingleses, quando está tratando justamente da miscigenação, é revelador de suas compreensões sobre o índio. Ele diz: "O amorozo português, ao invés do inglez do Norte, e muito felizmente para o Brazil, não repugnou enlaçar-se, legitimamente ou não, com a selvagem filha do paiz". (VERÍSSIMO, 1887, p. 297).

Todavia não bastava cruzar mais as raças ou promover a migração de raças "mais fortes" para se misturar com a nativa, como chegou a indicar Veríssimo ao tratar da ocupação da Amazônia para bem se explorar seus recursos naturais. Recorrendo à história, ele vai defender que esta nova raça miscigenada era "talvez aperfeiçoável".

Com o pensamento crítico voltado para a civilização que a modernidade ensejava e verdadeiramente preocupado com as desigualdades regionais tão agudas no território brasileiro, José Veríssimo, "um homem de boa vontade" e árduo servidor de sua Pátria, como ele mesmo se autodenominava, não poderia encontrar outro caminho mais digno para nosso País que não a educação escolar.

\section{REFERÊNCIAS}

ACADEMIA BRASILEIRA DE LETRAS (Brasil). Epistolário Acadêmico Carta de José Veríssimo a Afrânio Peixoto. Revista da Academia Brazileira de Letras, Rio de Janeiro, v. 21 e 33, n. 101, p . 95-119, maio 1930a.

ACADEMIA BRASILEIRA DE LETRAS (Brasil). Epistolário Acadêmico Carta de José Veríssimo a Afrânio Peixoto. Revista da Academia Brazileira de Letras, Rio de Janeiro, v. 21 e v. 33, n. 101, p. 108, maio 1930b.

BEZERRA NETO, José Maia. José Veríssimo: pensamento social e etnografia da Amazônia (1877-1915). Dados, Rio de Janeiro, v .42, n. 3, p. 539-564, 1999.

BHABHA, Hami K. Narrando a nação. In: ROUANET, Maria Helena. Nacionalidade em questão. Rio de Janeiro: Universidade do Rio de Janeiro/IL, 1997.

BOBBIO, Norberto. Dicionário de política. Brasília: Editora da Universidade de Brasília, 1986.

CARONE, Edgard. A primeira república. Texto e contexto: 1889-1930. São Paulo: Difel, 1969. 
. O tenentismo. São Paulo: Difel, 1975.

CARVALHO, José Murilo de. A formação das almas: o imaginário da república no Brasil. São Paulo: Companhia das Letras, 1991.

. Os bestializados: o Rio de Janeiro e a República que não foi. São Paulo: Companhia das Letras, 1991.

CUNHA, Euclides. Os sertões. Rio de Janeiro: Francisco Alves, 1995. (1 ${ }^{\mathrm{a}}$ edição 1902).

.À margem da história. São Paulo: Martins Fontes, 1999. (1ª edição 1909).

LAFFER, Celso. O significado de República. Estudos Históricos, Rio de Janeiro, v. 2, n. 4, p. 214-224, 1989.

LÉVINE, Roberto M. O sertão prometido: o massacre de canudos no nordeste brasileiro. São Paulo: Edusp, 1995.

PEREGRINO JÚNIOR. José Veríssimo - homem de carne e osso. Revista da Academia Brasileira de Letras, Rio de Janeiro, v. 93, n. 57, p. 9-21, jan./jun. 1957.

PRISCO, Francisco. José Veríssimo: sua vida e suas obras. Rio de Janeiro: Bedeschi, 1937.

ROMERO, Sylvio. Zéverissimações ineptas da crítica (repulsas e desabafos). Porto: Oficinas do Commercio do Povo, 1909.

VERÍSSIMO, José. Primeiras páginas: viagens ao sertão, quadros paraenses e estudos. Belém: Typografia Guttemberg, 1878.

. As populações indígenas e mestiças da Amazônia: sua linguagem, suas crenças e seus costumes. Revista Trimestral do Instituto Histórico e Geográphico Brazileiro, Rio de Janeiro, 1887.

. A educação nacional. Rio de Janeiro: Francisco Alves, 1906.

. Gregório de Mattos. Revista da Academia Brazileira de Letras, Rio de Janeiro, v. 2 e v. 4, n. 7, p. 27-44, 1912.

Texto recebido em 19 de abril de 2009.

Texto aprovado em 02 de maio de 2009. 